\title{
KAJIAN ATAS WACANA TASAWUF DAN KEUTUHAN SOSIAL ERNEST GELLNER
}

\author{
Abdul Kadir Riyadi \\ Universitas Islam Negeri Sunan Ampel Surabaya, Indonesia \\ E-mail: riyadi.abdulkadir@gmail.com
}

\begin{abstract}
This article seeks to scrutinize the thought of Ernest Gellner particularly his idea of tasawuf and its relation to social cohesion. He has raised a number of questions concerning the relation of Islam and tasawuf with modernity, which attract the attention of other scholars in the field. By modernity he means secularism, industrialism and nationalism. Motivated by secular and orientalist ideals, Gellner seems to have no ground in the "normative" aspect of Islam. This study finds that he is equally not consistent. In the first instance, he tends to argue that Islam must be excluded from modernity because it is not in conformity with it. Then he speaks of what he calls higher Islam and lower Islam, the former being in line with modernity while the latter is not. With regard to this distinction, he urges that Muslim society undergoes what he calls a "transition" from the lower to the higher Islam if it is to join the modern society and be part of the "cohesive world". The lower Islam should be left out because it teaches magic and encourages poverty. By bringing up this distinction, and not sticking to the consistent paradigm, Gellner's thought on Islam and tasawuf vis-à-vis modernity is-it may be judged-dichotomous and even perplexed.
\end{abstract}

Keywords: Tasawuf; modernity; social cohesion; transition.

\section{Pendahuluan}

Tidak dapat dipungkiri bahwa kajian sosiologi agama dalam masyarakat Islam, dalam beberapa dekade terakhir ini, dipengaruhi oleh gagasan besar yang diusung oleh Ibn Khaldūn. Sosok ini menyediakan kerangka yang memadahi bagi usaha mengembangkan wacana baru di bidang ilmu sosiologi. Pada masanya, gagasan sosiologis yang ia tawarkan sangat baru. Namun seiring dengan perkembangan ilmu, wacana yang ia tawarkan tidak lagi mencukupi untuk memahami fenomena sosial yang terus berkembang. 
Kebutuhan untuk memperluas cakupan teorinya pada satu sisi, dan juga teori sosiologi pada sisi lain, terasa sangat mendesak. Sifat dasar masyarakat terus mengalami pergeseran sebagai akibat dari perubahan faktor-faktor yang membentuk dan mempengaruhinya. Definisi masyarakat dan batasan-batasannya terus mengalami perubahan.

Pada sisi lain, belum banyak usaha untuk memahami masyarakat atau organisasi sosial dari sudut pandang spiritual atau sufistik. Modernitas yang terkesan sengaja meminggirkan agama dan dimensi spiritualnya semakin membuat perspektif spiritual atas masyarakat tidak saja terdengar aneh tapi juga terlupakan. Referensi yang pernah ditulis tentang "sosiologi spiritualitas" baik di dunia Islam maupun Barat sangat sedikit. Dan yang sedikit ini, terutama di Barat, justru memahami konsep spiritualitas secara reduksionis, dalam artian tidak menganggapnya sebagai bagian dari agama. Kajian tentang "sosiologi tasawuf" pada sisi lain selama ini masih belum ada, terutama yang bertujuan menciptakan paradigma teoretis. Kajian di bidang ini baru bersifat aplikatif dalam artian hanya menyorot fenomena sufistik tertentu dengan menggunakan teori sosiologis yang tersedia.

Yang lebih memprihatinkan adalah, sedikit sumbangsih yang ada justru mengaburkan makna dan konsep tasawuf. Dalam sosiologi modern, tasawuf sering dianggap menyerupai spiritualitas pada umumnya. Tasawuf adalah bagian integral dari Islam, sedang spiritualitas sementara ini dimaknai sebagai gerakan keluar dari agama dan meninggalkan norma-norma yang melekat padanya. Secara ekstrem, spiritualitas kadang diartikan sebagai bentuk pemberontakan kepada agama.

Ibn Khaldūn dapat dijadikan sebagai kerangka pijak untuk memulai proyek ini. Walau ia tidak pernah bicara mengenai sosiologi tasawuf sebagai sebuah kerangka teoretis, namun pemikirannya sudah menjangkau persoalan peran sosial yang dapat dimainkannya. Gagasannya tentang 'asabiyah dan kohesi sosial, misalnya, sangat menarik untuk digunakan sebagai alat baca untuk memahami masyarakat dan dimensi spiritualnya.

Karena konteks sejarah yang melahirkannya, teori Ibn Khaldūn terasa tidak cukup jika digunakan begitu saja tanpa adanya pembaharuan, penambahan atau bahkan koreksi. Teori Ibn Khaldūn ini bagus pada masanya, tapi tidak selamanya cocok untuk masa yang berbeda. Atas dasar inilah para pakar sosiologi seperti Ernest Gellner terpanggil untuk membaca ulang teori ini dan, setelah digabungkan 
dengan teori lain, menggunakannya untuk menjelaskan fenomena tasawuf. Inilah yang akan diangkat dalam pembahasan ini, yaitu wacana Gellner mengenai tasawuf dan hubungannya dengan persoalan kohesi sosial. Secara umum, sosiologi Gellner mengenai tasawuf adalah warisan dari semangat Ibn Khaldūn walau secara muatan dan landasan teoretis tidak selamanya demikian.

Dalam tulisan ini, pandangan Gellner diungkap apa adanya termasuk penilaiannya tentang tasawuf, dan juga Islam, yang kadang subjektif. Ideologi orientalisme diyakini sangat membentuk karakter dan pemikirannya, sehingga melahirkan gagasan yang cukup kontroversial. Tidak sedikit yang mempertanyakan kompetensinya di bidang kajian ilmu tasawuf dan Islam. Namun, ia telah meraih reputasi dunia di bidang ilmu sosiologi, sejarah, budaya dan peradaban. Terlepas dari "kekonyolan" yang ia ciptakan, ia tetap layak untuk dikaji.

\section{Ernest Gellner: Penggungat Agama}

Kiprah Ernest Gellner dalam pengembangan ilmu sosiologi tidak dapat dipungkiri. Ia telah mendedikasikan seluruh hidup dan karirnya untuk memberikan kontribusinya dalam bidang ilmu ini. Tidak sedikit yang menerima pandangan dan gagasannya, walau banyak pula yang menolaknya. Pemikirannya tentang Ibn Khaldūn, tasawuf dan masyarakat Muslim merupakan salah satu yang membuat namanya meroket dan dikenal di hampir seluruh dunia. Pandangannya mengenai dunia Islam menjadikannya sosok yang dicintai sekaligus dicaci. Ada yang menuduhnya sengaja menyudutkan Islam dan memposisikannya pada derajat inferior di hadapan peradaban Barat.

Terlepas dari kontroversi yang diciptakannya, memotret apa yang ada di benak Gellner tetaplah penting antara lain untuk: pertama, memahami perkembangan wacana Ibn Khaldūn di dunia Baratmodern; kedua, memahami sejauh mana perdebatan yang sudah, dan sedang terjadi, tentang tasawuf dan berbagai dimensinya terutama di kalangan sarjana Barat, dan; ketiga, mengetahui bagaimana seorang "orientalis" sepertinya menempatkan tasawuf berikut aspek sosialnya dalam kancah kajian Islam di Barat.

Bagi yang pernah membaca karya dan pemikiran Gellner akan terkesan dengan keluasan wawasan dan kedalaman pengetahuannya. Namun bagi kalangan tertentu ia tidak lebih dari seorang oportunis yang hanya ingin mencari sensasi semata. Daniel Martin Varisco, 
misalnya, menyebut pemikirannya telah "mengaburkan Islam", dan menilai karyanya "tidak layak untuk dibaca". ${ }^{1}$

Gellner berasal dari keluarga berdarah Jerman-Yahudi. Ia lahir di Praha pada tahun 1925 dan tinggal di sana sampai tahun 1939. Ia pindah ke Inggris bersama kedua orang tuanya pada usia 13 tahun dan menetap di sana sebagai warga negara Inggris. Dari sekian banyak imigran yang pernah hijrah ke Negeri Ratu Elizabeth, ia termasuk yang paling brilliant. Menjelang akhir hayatnya ia pindah lagi ke Praha tempat kelahirannya dan meninggal di sana pada tahun 1995.

Sebagai seorang Yahudi, ia konon tidak nyaman dengan identitas keagamaannya. Menurut John A. Hall, Gellner mengganggap identitasnya itu sebagai beban. Dia ingin hidup "normal" dan diperlakukan "secara normal". Dia tidak ingin "terpenjara" hanya karena lahir sebagai Yahudi. Selama identitas itu ada dalam dirinya, ia merasa "dipaksa dari luar". 2 Atas dasar inilah, ia menanggalkan baju agamanya dan memilih menjadi ateis. Hanya saja, sentimen keagamaannya tetap melekat pada dirinya terutama terkait dengan apa yang ia sebut sebagai penindasan atas orang Yahudi. Baginya, "penderitaan orang Yahudi oleh Hitler lebih menyita perhatiannya dari pada kota suci Yerussalem". ${ }^{3}$

Sebagian orang memandang Gellner sebagai penganut paham Materialisme atau Marxisme. Itu ada benarnya, jika melihat cara dia menafsirkan pemikiran Ibn Khaldūn yang kental dengan aroma materialistik. Ada pula yang memandangnya sebagai kepanjangan tangan dari filsafat Rene Descartes, David Hume dan Immanuel Kant. Ini juga benar mengingat ia sangat mengagumi para tokoh itu dan sering menggunakan pandangan mereka sebagai landasan pijak.

Pada awal perjalanan akademiknya, Gellner belajar filsafat di Universitas Oxford pada tahun 1945-1947. Walau hanya beberapa tahun belajar filsafat, penguasaannya terhadap bidang ilmu ini sangatlah luas. Ia memiliki bakat bawaan yang handal sebagai pemikir dan filsuf. Nantinya, ketika ia menjadi pakar di bidang ilmu lain,

1 Lihat Daniel Martin Varisco, Islam Obscured: The Rhetoric of Anthropological Representation (New York: Palgrave McMillan, 2005).

${ }^{2}$ Lihat John A. Hall, Ernest Gellner: An Intellectual Biography (London, New York: Verso, 2011). Di antara para pemerhati pemikiran dan biografi Gellner, Hall adalah yang paling produktif. Di samping menulis biografi di atas, ia telah pula mengedit buku yang terdiri dari tulisan para tokoh tentangnya dengan judul The Social Philosophy of Ernest Gellner.

${ }^{3}$ Ibid., 90. 
sentuhan filosofis tidak pernah sirna dari pemikirannya. Ia menulis satu karya di bidang ilmu filsafat dan terbit pada tahun 1959. Judulnya Words as Things. Buku ini ia tulis tidak saja untuk menuangkan gagasan filosofisnya namun juga sebagai bentuk kritik terhadap filsafat.

Entah apa yang mengganggu perasaan dan pikirannya, kritik ini terasa begitu pedas dan menohok. Ironisnya, yang menjadi sasaran kritik adalah para gurunya seperti Ludwig Wittgenstein, pembesar filsafat di Oxford. Tanpa tedeng aling-aling, Gellner yang kala itu masih terbilang "ingusan" mendobrak status quo dan menuduh para pemangku tradisi filsafat di kampus itu tidak mengerti konsep filsafat. Ia juga menyasar tradisi filsafat di Cambridge dan secara khusus menyudutkan Michael Oakeshott yang ia sebut "orang yang tidak berguna".

Kritiknya yang menusuk dan tanpa ampun nyaris mengguncang sendi dan pondasi kefilsafatan di kedua kampus ini. Mereka yang terusik menyerang balik, dan Gellner yang belum mapan secara pemikiran maupun karir nyaris terpental dan terbuang dari almamaternya. Namun berkat jasa Bentrand Russel, ia selamat. Russel membentenginya dan mendukung gagasannya. Ia bahkan memberi kata pengantar terhadap edisi baru Words as Things.

Selama menjadi dosen, Gellner tidak saja mengajar di Oxford namun juga di berbagai kampus terkemuka di Inggris dan dunia. Ia aktif memberi ceramah ilmiah di pusat-pusat kajian. Ia fasih bicara mengenai berbagai isu agama, peradaban, organisasi sosial, nasionalisme, demokrasi, modernisme, post-modernisme, sekuarisme dan lain sebagainya. Ia juga menguasai berbagai ilmu pengetahuan mulai dari filsafat, sosiologi, antropologi hingga bahasa dan politik. Ia kadang menyebut dirinya sebagai ahli antropologi sosial. Namun ia juga mengerti dengan baik ilmu sejarah dan budaya. Selain sebagai dosen, ia memiliki kegemaran mendaki gunung.

Perjalanan hidup dan karir akademiknya dipotret dengan baik oleh Hall yang menulis Ernest Gellner: An Intellectual Biography. Dalam karya ini, Hall memahami Gellner tidak saja sebagai individu, namun juga sebagai produk dari zaman dan fase sejarahnya. Ia mencoba sensitif dalam memposisikan dirinya sebagai penafsir dan Gellner sebagai objek penafsirannya. Ia menyadari bahwa sejarah tidak saja tentang peristiwa, namun juga tentang makna yang terselip dalam peristiwa itu. Tugasnya sebagai penulis biografi adalah mengungkap dan membongkar makna yang tersembunyi tanpa harus merusak unsur- 
unsur kecil yang saling terkait yang membentuk sejarah itu. Artinya, Gellner tidak saja dibahas sebagai objek yang dibentuk oleh sejarah tapi juga subjek yang turut membentuknya.

Hall membagi fase kehidupan Gellner menjadi dua bagian besar. Fase pertama adalah kepindahannya dari Praha ke Inggris, sedangkan fase kedua adalah masa setelah itu hingga kematiannya. Fase pertama merupakan tahapan pencarian jati diri. Ini merupakan tahapan paling sulit dalam hidup Gellner. Sebagai anak yang belum dewasa, tidak mudah baginya hidup di tengah masyarakat yang serba beda. ${ }^{4}$ Tidak saja beda bahasa, tapi juga kebiasaan dan gaya hidup. Agama menjadi faktor yang paling menyulitkan hidupnya. Agama terasa seperti tembok yang memisahkan dirinya dengan lingkungannya. Nantinya ketika dewasa, ia sering memberontak dan terang-terangan menyatakan bahwa "“'agama itu sombong". ${ }^{5}$ Ia benci terhadap orangorang Yahudi di sekitarnya termasuk Ludwig Wittgenstein dan Isaiah Berlin. ${ }^{6}$

Nuansa "kesombongan agama" ini sangat terasa tidak saja dalam komentar Gellner tentang agama Yahudi, namun juga dalam narasinya tentang agama-agama lain terutama Islam. Kebetulan Islam adalah satu-satunya agama yang menarik perhatiannya. Bahkan ada kesan seolah Islamlah yang ia maksud sebagai "agama yang sombong" itu. Setiap kali bicara tentang Islam, ia berusaha menampilkannya sebagai agama yang ingin memonopoli kebenaran dan kekuasaan, alat untuk memuaskan ambisi segelintir orang untuk menguasai dunia.

Objektivitas Gellner kadang muncul di tengah subjektivitasnya itu. Ia tidak keberatan mengakui Islam sebagai satu-satunya agama yang memiliki pertahanan kuat menghadapi perubahan besar di era modern ini. ${ }^{7}$ Gellner tertarik pada Islam karena kemampuannya menghadapi perubahan yang terus terjadi. Islam memiliki daya adaptif yang tinggi tanpa harus menjadi korban dari perubahan itu. Gellner merasa aneh dengan agama ini. Ia penasaran karena Islam selalu "membantah" teori-teori yang ia usung.

Ada empat tema yang menjadi perhatian Gellner, yaitu: pertama, filsafat sejarah dan usaha untuk memahami hukum-hukum yang

${ }^{4}$ Ibid., 102. Dalam ungkapan Hall, di samping menganut paham ateisme, Gellner juga memperjuangkan apa yang ia sebut sebagai "teologi modernis" untuk mengkritik agama. Ibid., 239.

${ }^{5}$ Ibid., 31.

${ }^{6}$ Ibid., $91,109$.

${ }^{7}$ Ernest Gellner, Muslim Society (Cambridge: Cambridge University Press, 1995), 104. 
mengendalikan perubahan dalam masyarakat; kedua, persoalan kebangsaan atau nasionalisme, relativisme dan universalisme dalam filsafat; ketiga, kemunculan sains dan perannya dalam dunia modern, dan; keempat, kajian sosiologi Islam. Hall menyederhanakan empat tema tersebut menjadi dua, yaitu perubahan sosial dan sosiologi Islam.

Bagi Gellner dua tema ini saling terkait dan tidak dapat dipisahkan. Di era yang mengalami perubahan cepat ini, Islam adalah faktor yang paling dominan baik pada tataran lokal maupun global. Islam sendiri adalah perubahan, dan terus terlibat dalam proses perubahan yang terjadi pada semua lini.

Menyadari peran penting Islam dalam konstelasi kehidupan modern, Gellner memutuskan menulis disertasinya di Universitas Oxford tentang tasawuf dengan judul The Organisation and Role of a Berber Zawiyah, dan selesai pada tahun $1954 .{ }^{8}$ Disertasi ini merupakan usaha awal untuk menjelaskan Islam sufistik di Maroko yang terus berdinamika menghadapi perubahan. Gagasan utamanya adalah bahwa para sufi memiliki peran besar dalam memimpin perubahan. Mereka adalah pemain utama tidak saja dalam urusan agama, namun juga dalam perihal sosial, politik dan ekonomi.

Pada aspek teoretis, yang menonjol dari disertasi ini antara lain adalah kehadiran Ibn Khaldūn yang sangat kuat. Teori Islam pedesaan dan Islam perkotaan berikut solidaritas dan kohesi sosial menjadi alat baca yang paling penting. Itu kemudian digabung dengan teori oskilasi ala David Hume dan teori sosial ala Max Weber. Jadilah sebuah orkestra antara Islam dan Barat dalam sebuah sajian yang unik namun kontroversial.

Hanya saja tidak sedikit yang kecewa dengan disertasi ini. Setidaknya ada tiga kritik yang muncul karenanya. Pertama, ada yang melihat aspek teoretisnya dan menyayangkan pemilihan Hume dan Weber. Tokoh ini adalah produk budaya Barat dan tidak selamanya sesuai untuk memotret atau menjelaskan fenomena masyarakat ArabIslam. Kedua, ada yang melihat aspek substansinya dan menemukan bahwa disertasi ini kacau dan tidak bernilai. Tidak ada yang baru di dalamnya terutama bagi mereka yang mengenal baik Islam di wilayah ini. Ketiga, disertasi ini basi karena Gellner sendiri di kemudian hari

\footnotetext{
8 Terdapat sedikit keanehan tentang disertasi ini. Dalam naskah yang berbentuk pdf, judul disertasi dicoret dan diganti dengan tulisan tangan menjadi The Role and Organisation of a Berber Zawiyah.
} 
merubah pandangannya tentang Islam dan melihatnya sebagai antikemajuan. $^{9}$

Apapun itu, disertasi ini menandai dimulainya petualangan panjang tentang sebuah agama yang sedang "naik daun" oleh seorang "orientalis" yang kontroversial. Disertasi ini juga menjadi saksi telah terjadinya drama dalam diri seorang penafsir tentang peran Islam di pentas dunia. Apa yang ada di benak Gellner tidak lain adalah representasi dari sikap orientalis tentang agama ini.

Pasca-menyelesaikan disertasinya, Gellner terus memperhatikan perkembangan Islam dan mencoba menghubungkannya dengan isuisu lain seperti nasionalisme, modernisme, post-modernisme, demokrasi, pluralisme, dan liberalisme. Hingga tahun 1969, ia berhasil melahirkan satu karya tentang sosiologi Islam yang merupakan kumpulan dari berbagai tulisannya yang tercecer di berbagai jurnal dan media. Karya itu berjudul Saints of the Atlas yang diterbitkan ulang pada tahun 1981 dengan judul Muslim Society. Dalam karya ini terdapat 12 artikel yang sebagian besar merupakan kajian tentang tasawuf dan masyarakat sufi di Maroko. Walau tidak koheren secara teoretis dan substantif, seperti yang Gellner sendiri akui, karya ini tetap layak mendapat apresiasi. Lagi-lagi, dalam karya ini Gellner mempertontonkan gejolak intelektual yang ia rasakan tentang Islam. Perasaan kagum dan sentimen, ragu dan yakin, hormat dan sinis campur aduk dalam buku ini. Mirip panggung gembira, buku ini menampilkan drama yang diperankan secara solo oleh aktor yang tidak pernah berhenti bergerak dan menari. Kadang tariannya terbaca, namun kadang pula terasa tak tentu arah.

Revolusi Islam di Iran yang terjadi pada tahun 1979 semakin membuat Gellner risau. Bukan karena ia khawatir Eropa akan dikuasai Islam, melainkan karena revolusi ini meruntuhkan teorinya tentang Islam bahwa agama ini anti-perubahan. Dengan revolusi ini ia meluncurkan teorinya bahwa "Islam adalah agama fundamentalis".

Teori ini tak ayal menciptakan kontroversi. Tidak sedikit koleganya dari sesama orientalis yang keberatan dengannya. Namun

\footnotetext{
${ }^{9}$ Kritik terhadap disertasi Gellner dapat ditemukan terutama dalam karya Hall. Lihat John A. Hall dan Ian Charles Jarve (eds.), The Social Philosophy of Ernest Gellner (Amsterdam and Atlanta: Rodopi, 1996); Sinisa Maleseciv dan Mark Haugaard (eds.), Ernest Gellner and Contemporary Social Thought (New York: Cambridge University Press, 2007).
} 
ada pula yang mendukungnya. ${ }^{10}$ Di tengah kontroversi itu, ia berkarya melahirkan banyak buku dan artikel. Jumlah buku yang ia tulis mencapai kurang lebih 23 buku di bidang ilmu yang beragam. Words as Things (1959) merupakan karya pertamanya. Sedang karya terakhirnya adalah Language and Solitude (1998). Karyanya yang paling penting Nations and Nationalism terbit pada tahun 1983, di puncak karir akademiknya.

Sudah banyak yang menelaah karya dan pemikirannya baik dalam rangka mendukungnya atau menolaknya. Beberapa buku yang terbit tentangnya adalah Ernest Gellner and Contemporary Social Thought, terbit pada tahun 2007. ${ }^{11}$ Ada tiga pembahasan pokok dalam antologi ini, yaitu: pertama, masyarakat sipil, kekerasan dan kebebasan. Bagian ini secara garis besar bicara mengenai pandangan dan komitmen Gellner terhadap liberalisme. Kedua, ideologi, nasionalisme dan modernitas yang mengupas antara lain persoalan modernisasi dan industrialisasi. Salah satu tulisan pada bagian ini menyoroti pendapat Gellner bahwa nasionalisme hanyalah alat untuk memuaskan nafsu kalangan industrialis. Ketiga, Islam dan post-modernisme.

Pada bagian ketiga ini Kevin Ryan layak disebut disebut secara khusus. Ia antara lain menganggap bahwa Gellner gagal memahami post-modernisme dan kaitannya dengan nalar agama. Pada saat ia berbicara mengenai konsep ini, ia justru melangkah terlalu jauh ke dalam dimensi epistemologis post-modernisme dan melupakan dimensi ontologisnya. Akibatnya, menurut Ryan, Gellner gagal menemukan tali penghubung antara post-modernisme dan agama, dan hanya berkutat pada sisi rasionalitas konsep ini.

Michael Lessnoff, pada sisi lain, mempertanyakan dasar Gellner membagi Islam menjadi "Islam tinggi" dan "Islam rendah". Yang dimaksud dengan "Islam tinggi" adalah kelompok atau aliran yang menganut paham mainstream dalam bidang fikih, teologi dan syariah. Atau, "Islam tinggi" adalah kelompok mayoritas yang secara akademis sering disebut orthodox atau secara populer disebut Islam Abl al-Sunnab wa al-jamäah. Gellner terkadang menyebut kelompok ini dengan

10 Untuk kritik terhadap Gellner tentang berbagai pandangannya, lihat Sean McLoughlin, "Islam (s) in Context: Orientalism and the Anthropology of Muslim Societies and Cultures", Journal of Beliefs and V alues, Vol. 28, No. 3 (2007).

11 Untuk karya ini lihat Maleseciv dan Haugaard (eds.), Ernest Gellner and Contemporary Social Thought. 
fundamentalis karena kegemarannya "memonopoli kebenaran". ${ }^{12}$ Sementara itu "Islam rendah" adalah kaum sufi. Mereka disebut demikian karena cenderung terpinggirkan dalam komunitas Muslim dan seringkali membawa ajaran yang tidak biasa atau, dalam ungkapan Gellner, "berbau sihir". ${ }^{3}$

Ada tiga hal yang memberatkan Lessnoff atas pandangan Gellner. Pertama, penyebutan "Islam tinggi" sebagai kelompok fundamentalis sama sekali tidak ada dasarnya. Justru selama ini "Islam tinggi" menunjukkan tingkat fleksibilitas yang tinggi dalam pemahaman agama. Banyak di antara mereka yang berpikiran terbuka jauh dari kesan fundamentalis. Kedua, pandangan Gellner bahwa di era modern ini, "Islam rendah" telah tergusur oleh "Islam tinggi" juga tidak mendasar. Anggapan ini terbantahkan oleh perkembangan tasawuf yang masif di era modern. Ketiga, "Islam tinggi" menyediakan ruang yang luas bagi terwujudnya masyarakat industri di dunia Islam karena bersifat rasional. ${ }^{14}$ Gellner menilai "Islam rendah" yaitu tasawuf, tidak berpihak pada modernisasi dan industrialisasi karena sifatnya yang kolot, terbelakang dan literal dalam memahami agama. "Islam rendah" juga sering disejajarkan dengan sihir dan takhayul sehingga tidak sesuai untuk masyarakat modern yang rasional.

Selain itu ada pula kumpulan karya tentang Gellner dengan judul The Social Philosophy of Ermest Gellner. ${ }^{15}$ Buku ini lebih komplit dan komprehensif dengan tujuh bagian di dalamnya yaitu: a) latar belakang pemikiran, b) konsep bangsa dan nasionalisme, c) model-model pertumbuhan, d) Islam, e) ilmu pengetahuan, f) relativisme dan universal, dan g) filsafat sejarah.

Seperti yang nampak dari ketujuh bagiannya, buku ini dimaksudkan untuk mengupas tuntas pemikiran Gellner. Hampir semua tema yang menjadi perhatian Gellner dibahas dalam antologi ini. Di antara ketujuh bagian itu, bagian keempat merupakan yang paling menarik untuk diperhatikan. Pada bagian ini, dibahas mengenai pandangan Gellner tentang Islam. Lima pakar antropologi Islam turut memberikan sumbangsih di dalamnya, dua di antaranya layak disebut secara khusus, yaitu Abdellah Hammoudi yang menulis Segmentarity, Social Stratification, Political Power and Sainthood, dan Talal Asad yang

12 Comptes Rendu, "Book Reviews: Ernest Gellner and Contemporary Social Thought”, Canadian Journal of Sociology, Vol. 34, No. 1 (2009), 169-174.

${ }^{13}$ Ibid.

${ }^{14}$ Ibid.

${ }^{15}$ Lihat Hall dan Jarve (eds.), The Social Philosophy of Ernest Gellner. 
menulis The Idea of an Anthropology of Islam. Kedua kontributor ini adalah pemikir dengan reputasi istimewa sejajar dengan Gellner.

Dari keduanya, pemikiran Asad terasa lebih kuat dan bertenaga. Tulisannya mengandung kritik tidak saja terhadap Gellner, namun juga terhadap mental "keangkuhan orientalis" yang menjadi ciri khasnya. Asad memperlakukan Gellner sebagai bagian dari tradisi orientalis yang memandang rendah bangsa-bangsa Timur termasuk Arab-Islam. ${ }^{16}$ Ini bukan soal sentimen melainkan soal cara baca. Asad meyakini bahwa pola pikir orang Barat tidak selamanya cocok untuk membaca fenomena masyarakat Arab-Islam. Kesalahan terbesar Gellner adalah ia ingin memaksakan metode bangsa Eropa untuk menafsirkan budaya bangsa lain.

Itulah yang menjadi penyakit terberat Gellner. Ia terobsesi dengan ke-Eropan-an. Segala hal, termasuk Islam, ingin ia Eropa-kan. Jika tidak berhasil, ia menyebutnya pembangkangan, atau dalam istilahnya sendiri fundamentalisme. Dengan standar Eropa pula ia mengajukan pertanyaan, mengapa kebanyakan dunia Islam tidak dapat mendirikan sesuatu yang menyerupai negara modern? Yang ia maksud dengan negara modern adalah yang memperjuangkan nilai-nilai "pencerahan" dan pluralisme liberal. Islam ia nilai sebagai agama teokratik dan totaliter.

Lessnoff yang menulis Emest Gellner and Modernity memuja Gellner dalam hal konsep nasionalisme, filsafat sejarah hingga apa yang disebut Relativism and Cognitive Ethics. ${ }^{17}$ Namun soal Islam, tidak demikian. Gellner yang menyejajarkan Islam dengan teokrasi, dibantah oleh Lessnoff. Bahkan jika sejajar sekalipun, Lessnoff berani mengatakan bahwa teokrasi Islam dapat didamaikan dengan nilai-nilai demokrasi modern. ${ }^{18}$

Menurut Lessnoff, masalah Gellner terletak pada cara pandangnya mengenai seberapa jauh Islam dapat menopang, mendukung atau dipadukan dengan tiga pilar modernitas yaitu sekularisme, industrialisme dan nasionalisme. Bagi Lessnoff, berangkat dari pengalaman empiris, Islam bersifat adapatif terhadap tiga pilar ini. Kasus di beberapa negara Islam menunjukkan bahwa Islam dapat

${ }^{16}$ Lihat Talal Asad, "The Idea of an Anthropology of Islam”, dalam John A. Hall dan Ian Charles Jarve (eds.), The Social Philosophy of Ernest Gellner (Amsterdam dan Atlanta: Rodopi, 1996).

17 Tentang buku ini, lihat Michael Lessnoff, Ernest Gellner and Modernity (Wales: University of Wales Press, 2002).

${ }^{18}$ Ibid., 157. 
digabungkan dengan modernitas. Pendekatan yang ia gunakan adalah kontekstual. Namun bagi Gellner tidak demikian. Ia menggunakan pendekatan tekstual dan menghasilkan kesimpulan bahwa Islam menuntut "seluruh dimensi kehidupan diatur oleh hukum Tuhan". Islam ingin menguasai dunia. Karena itu, Gellner menilai, Islam adalah agama fundamentalis dan "tidak layak disertakan dalam kajian filsafat tentang modernitas". ${ }^{19}$

\section{Dunia tanpa Islam}

Jika Islam tidak layak masuk dalam kajian tentang modernitas, berarti masyarakat Muslim tidak boleh masuk dalam daftar masyarakat modern. Inilah kira-kira ending yang diinginkan oleh Gellner. Dengan mengkaji Islam dan masyarakatnya secara mendalam, ia ingin menunjukkan bahwa agama ini tidak memenuhi syarat minimal sebagai bagian dari masyarakat modern. Ia menegaskan, Islam akan mengganggu "pemahaman kita tentang masyarakat". ${ }^{20}$ Gellner membangun sebuah batasan tentang masyarakat modern di mana Islam tidak masuk di dalamnya. Alasannya adalah karena Islam gagal menyesuaikan diri atau mengadopsi tiga pilar modernitas, yaitu sekularisme, industrialisme dan nasionalisme.

Gellner tidak pernah mengartikan secara tegas apa itu sekularisme. Namun dalam semua kajiannya, ia menunjukkan dukungannya yang kuat terhadap apa yang ia sebut sebagai "rasionalisme pencerahan sekuler". ${ }^{21}$ Istilah ini merujuk kepada pandangan dunia Barat modern bahwa agama harus dipisahkan dari politik dan bahkan dari ruang publik secara umum. Sekularisme sendiri ditandai dengan tiga ciri sebagaimana disebutkan oleh Charles Tylor, yaitu: a) kemunculan ruang publik yang sekuler, b) kemandulan agama dan praktik keagamaan, dan c) perubahan pola pikir dan hidup masyarakat yang mengharuskan agama tunduk pada konteks sosial. ${ }^{22}$ Kebangkitan agama, terutama Islam, adalah apa yang ingin dilawan oleh Gellner. Seperti ideologi relativisme, Islam mengancam tatanan dunia modern. Relativisme bahaya karena tanpa tujuan, sedang Islam bahaya karena menolak kebebasan.

\footnotetext{
${ }^{19}$ Lihat Hall, Ernest Gellner: An Intellectual Biography. Mengenai pandangan Gellner bahwa Islam sejajar dengan fundamentalisme, lihat Ernest Gellner, Postmodernism, Reason, and Religion (London dan New York: Routledge, 1992).

${ }^{20}$ Lihat Hall, Ernest Gellner: An Intellectual Biography.

${ }^{21}$ Lihat Gellner, Muslim Society.

22 Charles Tylor, A Secular Age (Cambridge: Belknap Press, 2007), 20.
} 
Pilar kedua modernitas adalah industrialisme. Gellner menguraikan pandangannya tentang industrialisme dalam Plough, Sword, and Book. ${ }^{23}$ Dalam karya ini ia berbicara banyak tentang struktur masyarakat dengan mengaca kepada pengalaman Eropa. Ia membagi masyarakat menjadi tiga jenis yaitu masyarakat pemburu, petani, dan industri. ${ }^{24}$ Jenis yang pertama menjadikan pemenuhan kebutuhan dasar (terutama makan) sebagai tujuan paling utama dalam hidup. Mereka berburu untuk makan, dan hidup hanya untuk makan. Jenis yang kedua di samping ingin bertahan hidup dengan bertani juga memikirkan bagaimana mereka dapat berkembang dan mempertahankan identitas. Mereka mengembangkan organisasi sebagai cara untuk maju bersama. Kekuasaan menjadi ciri khas paling menonjol dalam masyarakat ini. Kekuasaan menentukan kekayaan, tapi kekayaan belum tentu menentukan kekuasaan. Ilmu pengetahuan dalam masyarakat ini hanya dibutuhkan untuk menjaga dan merawat keutuhan masyarakat. Budaya dibutuhkan sebatas untuk menjaga kesetiaan dan keutuhan serta nilai-nilai yang mereka anut.

Jenis ketiga adalah tipe masyarakat yang paling maju dan ideal, menurut Gellner. Masyarakat ini bersifat industrial, ditandai dengan adanya sistem pendidikan yang maju, ketersediaan pekerjaan yang merata, perkembangan ilmu pengetahuan yang cepat serta mobilitas ekonomi dan sosial yang massif. Persaingan keahlian menjadi satusatunya ukuran apakah seseorang akan menonjol dan meraih kekuasaan atau tidak. Ilmu tidak lagi menjadi faktor penentu untuk menjaga keutuhan. Ilmu adalah alat untuk memahami persoalan tertentu, dan sebagai sarana mengetahui sesuatu yang belum diketahui. Apa yang oleh Durkheim disebut sebagai generic rationality telah berubah menjadi instrumental rationality. Tidak ada sistem kasta di dalam masyarakat ini. Setiap orang dapat bersaing demi mendapatkan posisi yang baik dengan ilmu dan keahliannya. Dan yang paling penting, struktur masyarakat ini bersifat meritocratic. ${ }^{25}$

Gellner menegaskan bahwa industrialisme seperti yang sudah berkembang di Eropa adalah produk dari gerakan Pencerahan yang

23 Lihat Ernest Gellner, Plough, Sword and Book: The Structure of Human History (Harville: Collins, 1988).

${ }^{24}$ Ibid.

25 Jiri Musil, "Gellner's Philosophy of History: Interpretations and Problems", dalam John A Hall (ed.), The Social Philosophy of Ernest Gellner (Netherlans: Brill Rodopi, 1996), 159. Meritocratic adalah pola masyarakat yang berorientasi pada merit atau keunggulan. 
berhasil. Bentuk masyarakat ini harus dianut oleh seluruh lapisan masyarakat dari seluruh dunia. Ketertinggalan dari industrialisme adalah ancaman bagi masyarakat modern secara keseluruhan. Penolakan terhadapnya harus ditangani secara serius dan seksama. Gellner menyadari bahwa gelombang penolakan terhadap industrialisme bisa datang dari mana saja dan kapan saja terutama dari Islam. Karena itu ia mengingatkan bahwa usaha untuk menerapkan standar hidup modern harus dilakukan. Tidak seperti masyarakat pemburu dan petani, dalam masyarakat industrial sekat antar individu harus dihilangkan melalui apa yang ia sebut sebagai diseminasi pendidikan dan ilmu pengetahuan. Jika proses ini tidak berhasil maka proses terakhir, yaitu asimilasi budaya harus diambil. Dalam proses inilah, konsep nasionalisme menjadi sangat sentral dan penting.

Di antara isu-isu penting lainnya, nasionalisme mendapat perhatian paling besar dari Gellner. Ia menyampaikan visinya tentang konsep ini dalam Nations and Nationalism. Buku ini dinilai hebat dan membuatnya dinobatkan sebagai pioner di bidang kajian sosial-ilmiah tentang nasionalisme. ${ }^{26}$ Ada pula yang menyebutnya sebagai "filsuf nasionalisme". Yang patut diperhatikan, Gellner tidak pernah bicara mengenai nasionalisme kecuali mengaitkannya dengan fundamentalisme Islam. ${ }^{27}$ Kedua konsep ini ia tempatkan pada posisi yang saling berseberangan dan berlawanan.

Ia mengartikan nasionalisme sebagai "pedoman politik untuk mewujudkan kesatuan budaya dan politik". ${ }^{28}$ Definisi ini sangat berbeda dari yang ditawarkan antara lain oleh Charles Taylor dan James Tully di mana keduanya menekankan pada aspek keberagaman dalam nasionalisme ketimbang kebersatuan. Yang nampak dari proyek Gellner ini adalah keinginannya mewujudkan keseragaman dengan cara menghilangkan keberagaman. Modernitas dengan tiga pilarnya bertujuan untuk itu. Kohesi sosial berskala global yang melahirkan perdamaian dunia, hanya bisa dicapai ketika manusia diseragamkan. Gellner mendamba bahwa masyarakat yang berbeda dari segala penjuru dunia harus disatukan di bawah naungan payung yang sama, yaitu modernitas. Asimilasi budaya menjadi strategi utama bagaimana penyeragaman ini bisa diwujudkan. Maka, dengan nada menghentak ia

${ }^{26}$ Roland Dannreuther dan James Kennedy, "The International Relations of the “Transition": Ernest Gellner's Social Philosophy and Political Sociology" (Makalab-SGIR Par European Conference, Torino, 12-15 September, 1999), 20.

${ }^{27}$ Ibid., 5.

${ }^{28}$ Ernest Gellner, Nations and Nationalism (Ithaca: Cornell University Press, 1983), 1. 
berteriak, "sejarah modernitas telah menunjukkan bahwa masyarakat tradisional harus dihapuskan dan budaya tunggal tingkat tinggi harus dipaksakan". ${ }^{29}$

Di sinilah letak pertarungan wacana Gellner dengan Islam. Terlalu sulit baginya untuk menundukkan Islam. Dengan nada penuh kekhawatiran, ia mengeluh "Islam adalah cetak biru tatanan sosial". ${ }^{30}$ Artinya, sebagai tatanan sosial Islam tidak dapat digoyahkan. Ia sudah mapan. Inilah keluhan Gellner dalam seluruh karyanya tentang Islam.

Ketika ia diundang untuk menyampaikan The Tanner Lectures on Human Values di Harvard University pada tahun 1990, ia menyempatkan diri untuk curbat tentang Islam. ${ }^{31}$ Isinya antara lain mengakui bahwa konsep ummah dalam Islam sangatlah kuat, namun tidak sejalan dengan modernitas, khususnya nasionalisme, karena konsep tersebut intolerant. Ia lalu mengingatkan bahwa konsep ini akan memaksa dunia untuk memeluk apa yang ia sebut "doctrinaire unitarianism" yang dibawa Islam. ${ }^{32}$

Gambaran Gellner tentang Islam dengan doctrinaire unitarianisme ini sungguh menakutkan. Kekuatan Islam ia maknai sebagai ancaman dan bukan peluang. Ia berbicara tentang masyarakat global seolah dalam kondisi bahaya akan kemungkinan hegemoni Islam. Ia menganut pendekatan "The Clash of Civilizations" dalam menyikapi fenomena persaingan global. Seperti Samuel P. Huntington di Amerika, ia mendorong akuisisi oleh kekuatan utama atas kekuatan pinggiran.

Tesis besar Gellner adalah bahwa Islam tidak dapat menerima nilai-nilai modernitas dan nasionalisme serta menutup matanya akan kenyataan yang, faktanya, justru menunjukkan sebaliknya. Di dunia Islam banyak usaha untuk mengadopsi nasionalisme sebagai ideologi bangsa. Ia pun ia tidak mau menerima kenyataan bahwa tidak ada masyarakat Islam di dunia ini yang menolak konsep negara-bangsa. Bagi Gellner hanya kalangan Muslim reformis yang menerima

${ }^{29}$ Ibid.

${ }^{30}$ Gellner, Muslim Society, 1.

31 Tanner Lectures on Human V alues adalah serangkaian ceramah ilmiah tentang nilainilaii kemanusiaan yang disampaikan oleh para pakar yang terpilih. Ceramah ini sangat bergengsi dan hanya sarjana dengan reputasi tinggi yang diundang. Ada 9 universitas terkemuka di Amerika Serikat yang dipercaya untuk menjadi host bagi kegiatan ini.

32 Ernest Gellner, "The Civil and the Sacred" (Makalah--Harvard University, 20-21 Maret 1990). Yang ia maksud dengan "unitarianisme" adalah tindakan sepihak untuk mencapai tujuan tertentu tanpa memperdulikan kepentingan orang atau kelompok lain. 
nasionalisme. Itupun sebatas sebagai strategi politik untuk merebut kekuasaan. $^{33}$

Atas dasar inilah tidak sedikit kritikus yang memandangnya terlalu terobsesi dengan idealisme modernitas. Ia seperti hidup di dunia yang berbeda dan tercerabut dari kenyataan yang ada. Keberagaman sosial yang merupakan fenomena paling sederhana, ia tolak. Sedangkan keseragaman yang merupakan tujuan paling mustahil, ia perjuangkan. Predikatnya sebagai filsuf sejarah dan nasionalisme, tidak lantas membuatnya berpikir secara jernih dan rasional.

Talal Asad pernah mengkritiknya dan menyarankan agar ia lebih mengedepankan metode "genuine dialogue" dalam berinteraksi dengan peradaban lain. Namun ia menolaknya. Itu membuat Asad beserta beberapa kritikus lain seperti Edward Said dan Sami Zubaidah menyebutnya tanpa ragu sebagai kepanjangan tangan dari orientalisme dan imperalisme.

Para kritikus ini menyayangkan sikap Gellner yang memperlakukan dunia Islam sebagai masyarakat yang terbelakang. Seperti Max Weber ia meyakini Islam tidak akan pernah maju, tipikal pemikiran seorang imperialis-kolonialis Barat. Seperti Jane Austin dan Mark Twain di bidang sastra, ia menganut asumsi bahwa bangsa Timur itu pemalas, stagnan, budayanya tidak rasional, fanatik terhadap agama, absolutis dalam berpolitik, dan terlalu mistis. Dari sekian sikap negatif Gellner terhadap bangsa Timur, yang paling mengkhawatirkan Asad dan Zubaidah adalah aspirasinya untuk "menolak keberagaman dan memaksa dunia agar mengadopsi budaya tunggal". ${ }^{34}$

\footnotetext{
33 Teori ini mendapat kritik keras antara lain dari Hall. Lihat Hall, Ernest Gellner: An Intellectual Biography. Hall mengatakan bahwa justru di beberapa negara Islam, nasionalisme adalah kekuatan paling utama. Mungkin saja ada negara Islam yang menolak nasionalisme, tapi tidak ada negara Islam yang menolak konsep negarabangsa.

34 Talal Asad, "The Concept of Cultural Translation in British Social Anthropology", dalam James Clifford dan George Marcus (eds.), Writing Culture: The Poetics and Politics of Ethnography (Berkeley: University of California Press, 1986), 14164. Lihat juga, Talal Asad, The Idea of an Anthropology of Islam (Washington DC: Georgetown University Centre of Contemporary Arab Studies, 1986). Dalam karya ini Asad menyoroti karya Gellner yang berjudul Muslim Society. Ia menilainya "tidak memiliki wacana yang orisinil tentang Islam". Lihat juga, Satya P. Mohanty, Literary Theory and the Claims of History (Ithaca dan London: Cornell University Press, 1997), 131. Untuk kritik Zubaidah, Lihat Sami Zubaidah, "Is There a Muslim Society? Ernest Gellner's Sociology of Islam", Journal of Economy and Society, Vol. 24, No. 2 (1995).
} 
Asad dan Zubaida merasa perlu untuk menolak sikap ini. Mereka tergabung dalam kelompok Hull, yaitu sekelompok orang yang menentang proyek orientalisme yang diusung oleh Oxford dan Cambridge. Bagi kelompok ini, proyek "Kajian Islam" yang digagas oleh para orientalis bertujuan untuk membantu kepentingan Barat dalam menghadapi Islam.

Sementara itu, Said mengajukan kritik terhadap Gellner secara khusus dan orientalisme secara umum melaui karyanya Orientalism. Buku ini membangunkan sikap waspada terhadap bahaya dan prasangka orientalis, dan menggelorakan penolakan atas hegemoni Barat dalam ranah ilmu pengetahuan dan budaya. Suara Said terdengar sangat nyaring pada era 1970-1980 dan berhasil mengganggu sendisendi dunia akademik Barat yang mendukung konsep "tatanan dunia baru" ala Gellner. Inilah buku yang membuat para orientalis kecut, sesak napas dan kehilangan nomentum. Puncaknya, istilah orientalisme redup dan kini digantikan dengan istilah "Kesarjanaan Barat".

Gellner termasuk sosok yang terkena kritik Orientalism. Namun karya Said yang lain menghatam Gellner jauh lebih keras. Judulnya Culture and Imperialism. Tanpa tedeng aling-aling, Said menuduh Gellner dan orang-orang seperti dirinya sebagai pelayan kaum penjajah. Sontak saja Gellner berang. Ia menyerang balik. Perseteruan antara keduanya berlanjut di media massa dan menjadi konsumsi publik sebagaimana dilaporkan oleh harian The Independent edisi Minggu 6 Juni 1993 dengan heading An Academic Row Turns Personal (Perselisihan Akademik Menjadi Pertikaian Pribadi).

Selain Asad, Zubaidah dan Said, kritikus Gellner lainnya adalah Patricia Crone dan Michael Cook. Kritik lain disampaikan oleh Fred Halliday dan Charles Tripp yang menempatkan Gellner berada di antara neo-orientalisme dan kesarjanaan Barat. Neo-orientalisme adalah proyek lanjutan orientalisme. Tujuannya sama namun dengan semangat yang lebih membahana seperti yang dipertontonkan oleh Bernard Lewis dan, yang terbaru, Robert Spencer. Dalam wacana neoorientalisme, Islam adalah ideologi trans-nasional. Cirinya, menentang Barat, menolak memisahkan antara agama dan politik, tidak menghargai Hak Asasi Manusia dan menolak demokrasi. ${ }^{35}$ Khusus untuk Spencer, Islam dipatenkan sebagai agama teroris.

35 Bernard Lewis, The Political Languange of Islam (Chicago: Chicago University Press, 1988), 202. 
Halliday dan Tripp merasa bahwa kadangkala Gellner berada pada jalur yang sama dengan mereka. Namun tidak jarang pula mereka terbawa oleh asumsi yang berseberangan dengannya, yaitu yang memandang Islam sebagai agama moderat. Halliday dan Tripp sendiri mengusung gagasan bahwa Islam sejalan dengan demokrasi dan modernitas. Dalam konteks konstelasi global, agama ini menjadi korban dari kampanye negatif besar-besaran terhadapnya. Citra Islam sengaja diperburuk oleh pihak-pihak yang merasa terancam akan "kebangkitannya."

\section{Islam tanpa Tasawuf}

Membaca Gellner tampaknya tidak terlalu salah jika menyimpulkan bahwa ia menginginkan dunia yang kohesif, damai dan tenteram tanpa Islam. Kohesi sosial tingkat global hanya bisa dicapai jika dunia mengadopsi modernitas dengan tiga pilarnya, yaitu sekularisme, industrialisme dan nasionalisme. Cita-cita ini sulit terwujud selama masih ada Islam. Karena itu, tugas yang ia embankan pada dirinya adalah menafsirkan ulang doktrin Islam agar sejalan dengan peradaban modern dan sesuai dengan idealisme modernitas.

Sekularisme adalah nilai kemanusiaan, industrialisme adalah perangkat kesejahteraan ekonomi sedang nasionalisme adalah mekanisme mewujudkan solidaritas dan kohesi sosial. Ketiganya secara bersama bekerja menciptakan sebuah tatanan yang kohesif. Islam dianggap berada di luar karena sebagai tatanan, agama ini tidak dapat dikompromikan dengan tatanan yang lain.

Pada tataran politik bahkan ideologis, modernitas mewujud dalam bentuk negara-bangsa yang demokratik dan liberal. Kadang pula menjelma menjadi "Civil Society" (masyarakat sipil). ${ }^{36}$ Industrialisme berguna untuk menopang konsep negara-bangsa karena ia menyediakan peluang kesejahteraan materiel, sedangkan sekularisme adalah nilai yang melandasi ideologi dan "moralitas" bangsa itu. Menurut Gellner negara-bangsa yang demokratik dan liberal serta masyarakat sipil yang terbuka dan menghargai pluralisme adalah satu keharusan. Tanpanya, masyarakat akan mengalami tragedi. Islam tidak sesuai dengan skema ini karena sifatnya yang patriarkis dan unitarianis. $^{37}$

\footnotetext{
36 Gellner, "The Civil and the Sacred", 304.

37 Gellner menggunakan dua istilah ini (patriarki dan unitarianisme) dalam ceramahnya di Harvard University.
} 
Pandangan Gellner tentang Islam dan hubungannya dengan dunia modern bernuansa pesimistis dan konfrontatif. Ini adalah dampak dari metode Weberian yang ia gunakan. Ia lupa bahwa peradaban tidak monolitik dan tidak selamanya harus materialistik. Peradaban adalah hasil interaksi dari beragam budaya, tradisi, wacana, bahasa bahkan agama. Peradaban juga merupakan produk dari pemikiran manusia secara kolektif. Apa yang menjadi ciri khas dari sebuah peradaban di tempat tertentu tidak pernah lepas dari proses yang terjadi di tempat lain. Atas dasar inilah, tesis "spirit of capitalism" yang diajukan oleh Weber dan disetujui oleh Gellner sebetulnya dapat dipatahkan.

Uniknya, Gellner sendiri, terutama pada fase awal karir akademiknya, menyadari bahwa teori Weberian yang ia kembangkan mengandung banyak kelemahan. Ia bahkan menerima bahwa Islam memiliki budaya dan suprastruktur yang memadahi, semacam spirit of capitalism, setara dengan peradaban maju lainnya. Maka, ia membedakan antara apa yang ia sebut sebagai "Islam tinggi" dan "Islam rendah". Islam tinggi adalah dimensi yang maju dan siap lepas landas. Sedang Islam rendah adalah yang mengajak ke belakang. Islam tinggi bersifat rasional dan menekankan pada aspek keilmuan. Islam jenis ini berbasis pada syariah dan menjadikan penafsiran ulama sebagai legasi pemikirannya. Islam tinggi bersifat terbuka, komprehensif, dan memiliki potensi untuk menerima kemajuan, industrialisasi dan modernitas. Ulama Islam tinggi telah menciptakan apa yang ia sebut "kesatuan pandangan hidup" yang menuntun umat meraih pencerahan dan kemajuan. Karena tercerahkan, Islam tinggi meninggalkan praktik-praktik mistis yang berbasis pada tasawuf, ritual dan kultus individu.

Islam tinggi dianut oleh kaum reformis. Mereka memiliki ciri, a) berpendidikan tinggi, b) mendukung gagasan tentang identitas nasional dan konsep negara-bangsa, c) anti kolonial, d) anti westernisasi tapi menerima industrialisasi, dan d) anti elit-politik. Sebagai catatan, tiga ciri terakhir menjadi ukuran mengapa Islam tinggi, menurut Gellner, tetap pantas disebut fundamentalis. ${ }^{38}$

Menerima Islam tinggi dengan beberapa catatan dan menolak Islam rendah (tasawuf) secara total adalah garis pemikiran Gellner. Gagasannya adalah, jika masyarakat Muslim ingin menciptakan solidaritas dan kohesi internal, maka satu-satunya jalan adalah

${ }^{38}$ Lihat Lessnoff, Ernest Gellner and Modernity. 
menyingkirkan Islam rendah. Dalam sejarah, Gellner mencoba meyakinkan, kedua jenis Islam ini selalu terlibat perselisihan. Selama beratus-ratus tahun, perselisihan itu bahkan meluas ke berbagai tingkatan dan memicu konflik antar berbagai elemen dalam masyarakat. Baginya, sumber konflik itu adalah Islam rendah. Berbagai konflik seperti antara ulama fikih dan sufi, penguasa dan rakyat, proletar dan elit, petani dan pedagang, masyarakat desa dan kota, semuanya dipicu oleh perlawanan Islam rendah atas Islam tinggi.

Implikasinya, perbedaan dalam Islam, menurut Gellner, adalah fenomena yang tidak sehat. Berbeda dengan visi Nabi Muhammad yang memaklumi perbedaan (ikhtiläf) sebagai hal biasa bahkan menyebutnya sebagai anugerah, Gellner berpendapat bahwa perbedaan harus disudahi dan diarahkan kepada keseragaman (bomogenity) pemikiran dan budaya. ${ }^{39}$ Keseragaman inilah yang menjamin solidaritas; solidaritas menjamin kohesi; kohesi menciptakan ketentraman dan keamanan; dan keamanan menciptakan kesejahteraan. Keseragaman dapat diraih dengan cara, orang desa digiring ke kota, kekolotan diganti dengan kemodernan, tradisi diganti dengan rasionalitas, Islam rendah (tasawuf) ditinggalkan dan Islam tinggi dikumandangkan. Meminjam Hume, Gellner mencatat bahwa: "Kesuksesan agama terletak pada pengakuannya terhadap sesuatu yang rasional." ${ }^{40}$ Maka ia berujar bahwa: "Kemajuan Islam harus diukur tidak saja dari keberhasilannya menghindar dari pengaruh westernisasi namun juga dari kemampuannya meninggalkan jebakan tasawuf." ${ }^{41}$

Proses kepindahan dari keberagaman menuju keseragaman dan dari fase keterbelakangan menuju kemajuan ia sebut transisi. Ada dua proses transisi yang harus dilalui oleh masyarakat Muslim, yaitu: pertama, transisi dari Islam rendah menuju Islam tinggi, dan; kedua, dari Islam tinggi menuju modernitas. Proses pertama diperlukan agar

\footnotetext{
${ }^{39}$ Gellner, Muslim Society, 99.

${ }^{40}$ Lihat David Hume, Natural History of Religion (Stanford: Stanford University Press, 1957).

${ }^{41}$ Gellner, "The Civil and the Sacred", 316, 324. Berbeda dengan Gellner, Abdul Kadir Riyadi optimistis bahwa tasawuf memiliki kemampuan yang teruji untuk menyesuaikan diri dengan perubahan. Usaha beradaptasi dengan modernitas dapat dilakukan oleh tasawuf dengan catatan, pertama, tasawuf lebih terbuka terhadap kritik, kedua, tasawuf berubah menjadi adaptif dan adoptif terhadap perkembangan ilmu pengetahuan baru seperti sosiologi dan antropologi. Lihat Abdul Kadir Riyadi, Antropologi Tasanuf (Jakarta: LP3ES, 2014).
} 
Islam terlepas dari dimensi magis yang melekat dalam tasawuf, sedangkan proses kedua dibutuhkan sebagai mekanisme adaptasi agar Islam bisa menjadi bagian dari dunia modern yang plural, toleran, demokratik, liberal dan kohesif. Dengan kedua proses ini, Islam akan bertransformasi dari agama tradisional menjadi agama modern, bahkan dari agama menjadi "civil society", dari sistem keyakinan menjadi sistem sosial, sistem ibadah menjadi perayaan demokrasi, dari kesakralan menuju keprofanan.

Pengamatan yang ala kadarnya menunjukkan bahwa Gellner menganggap transisi internal dari Islam rendah menuju Islam tinggi sangat sentral. Tanpa itu, Islam tidak akan berhasil menjadi bagian dari dunia modern. Ia menganggap tasawuf identik dengan kejumudan salah satunya karena menolak keduniaan dan mengajarkan zuhd (asketisme, sikap anti dunia). Persoalannya adalah, ketika transisi tahap pertama berjalan belum tentu transisi tahap kedua akan berhasil. Gellner berkilah bahwa, pertama, hanya kaum reformis dalam Islam yang siap menjalani transisi ke arah modernitas, kedua, peran tasawuf terlalu kuat dalam Islam, dan, ketiga, Islam memiliki sifat selalu ingin kembali ke belakang walau sudah berhasil maju ke depan. Ada kalanya Islam sukses menjalani transisi tahap kedua, namun dengan cepat ia kembali ke akarnya, yaitu syariah. Bagi Gellner ini masalah. Pergerakan Islam yang menurutnya bersifat seperti ayunan atau "flux and reflux of religion", meminjam teori Hume, ia gambarkan sebagai anti-tesis dari peradaban Barat yang progresif.

Sifat maju-mundur seperti ayunan ini, ditambah dengan pengaruh tasawuf dan kecilnya gairah reformasi dalam Islam, menjadi penyebab utama mengapa masyarakat Muslim tidak pernah berubah. Menyikapi hal ini, Gellner fokus melakukan kritik terhadap tasawuf karena ia menganggapnya sebagai sumber masalah. Dia menyadari bahwa apabila ini berhasil, proses reformasi akan berjalan dan transisi ke arah modernitas dapat terlaksana. Yang ia maksud dengan reformasi adalah perubahan pola hidup dari berorentasi pada kultus individu menjadi pengagungan terhadap ilmu pengetahuan. Atau jelasnya, perubahan dari Islam rendah kepada Islam tinggi. ${ }^{42}$ Reformasi ini merupakan syarat bagi berjalannya proses transisi.

Kitik Gellner terhadap tasawuf adalah bagian dari strateginya untuk memenangkan "pertempurannya" dengan Islam. Ia menganggap Islam sebagai masalah karena gagasannya tentang

42 Ibid., 318. 
modernitas dan peradaban modern selalu "terbantahkan" oleh fenomena agama ini. Teorinya tentang sekularisme, industrialisme dan nasioalisme, tidak berlaku untuk masyarakat Muslim. Untuk menutupi ini, ia mengalihkan kesalahannya kepada Islam terutama tasawuf dan menuduhnya sebagai sarang sihir dan takhayul. ${ }^{43}$

Penilaian ini tidak terlalu mengejutkan mengingat sudah banyak orientalis dan sosiologis Barat yang melakukan hal serupa seperti Clifford Geertz, Jonathan Smith dan Anthony H. John. Yang patut disayangkan adalah, dimensi keilmuan dalam tasawuf yang begitu subur justru dilupakan. Para orientalis ini tidak sadar atau sengaja menutup mata atas prestasi tasawuf yang begitu gemilang. Tasawuf mencapai puncak kejayaannya justru pada masa keemasan Islam ketika ilmu pengetahuan berkembang pesat dan rasionalitas menjadi primadona pemikiran. Para sufi memainkan peran penting dalam capaian ini. Keilmuan mereka telah memberikan kontribusi yang tak terhingga. Mata rantai yang terbangun selama seribu tahun lebih ini menjadikan tasawuf sebagai tradisi yang kaya dan beragam. Naif jika menilai tasawuf dari satu sudut pandang saja. Apalagi satu sudut pandang ini tidak benar adanya.

Jika mau bersikap objektif, sesungguhnya para orientalis harus memperbaiki cara pandang mereka terhadap Islam, tasawuf dan budaya Timur pada umumnya. Varisco telah menyurakan ini. ${ }^{44}$ Ia mengingatkan orientalisme "mengaburkan pemahaman para orientalis tentang Islam". Memahami kewalian dan karamah sebagai takhayul dan sihir adalah kesalahan yang fatal.

Jika persoalannya adalah mengemansipasi masyarakat dari unsur magis, maka itu dapat diterima, dan para sufi pasti akan menjadi orang pertama yang menyepakatinya. Namun ketika yang disebut dengan magis adalah tasawuf, maka permasalahannya menjadi berbeda. Gellner setuju dengan Weber bahwa moderninasi dapat terjadi dengan rasionalisasi agama, dan rasionalisasi agama membuat dunia terbebas dari unsur magis. Tesis ini dapat diterima meski masih membutuhkan penjelasan lebih jauh mengenai makna rasionalisasi. Namun persoalan muncul ketika Gellner menyandingkan tasawuf dengan magis. Definisi dan pemahamannya tentang tasawuf menjadi rancu, dan kerancuan ini tidak saja berdampak pada kesalahpahamannya terhadap

\footnotetext{
43 Ibid., 316.

44 Varisco, Islam Obscured, 57.
} 
tasawuf dan Islam, namun juga memunculkan kerumitan tersendiri dalam sistem dan pola pemikirannya.

Pemahaman Gellner tentang tasawuf tidak berakar pada tradisi tasawuf itu sendiri. Ia mengabaikan ajaran para sufi yang sudah dibangun selama seribu tahun lebih. Dari sudut pandang Filsafat Ilmu, ini keliru karena mengabaikan sesuatu yang paradigmatik dan beralih ke wacana yang menciptakan krisis dan anomali akademis.

Kekeliruan lain karena kesalahan metodologis terjadi ketika ia menyamakan tasawuf (Islam rendah) dengan gereja dan Islam tinggi dengan kaum reformis di Eropa. ${ }^{45}$ Sementara kaum reformis menghendaki kemajuan dengan gerakan pencerahannya, kaum gereja justru mempertahankan status quo meski harus dibayar dengan keterbelakangan dan kejumudan. Ketertutupan terhadap ilmu pengetahuan dan irrasionalitas dalam ajaran keagamaan adalah ciri khas gereja Eropa yang ia rasakan ada dalam tasawuf.

Ada dua hal lain yang membuat tasawuf menyerupai gereja dalam pandangannya, yaitu konsep ritual untuk kultus individu dan gagasan mengenai masyarakat dan kepemimpinan. Terkait kultus individu, konsep kewalian dan kesucian dalam tasawuf sangat mirip dengan yang ada dalam gereja. Gellner melihat bahwa baik wali dan "orang suci" dalam gereja sama-sama mengklaim bahwa mereka adalah orang pilihan Tuhan. Mereka meyakini memiliki derajat yang lebih tinggi dibandingkan dengan orang kebanyakan. Tradisi sufi dan gereja memandang pemuka agama mereka sebagai sosok panutan dengan imunitas yang membuatnya terbebas dari kesalahan. Dalam Muslim Society, Gellner membahas secara khusus persoalan kesucian (sanctity) ini. Ia menyebut, terdapat kemiripan antara tasawuf terutama di Afrika Utara dengan, kali ini ia menyebut, tradisi Protestan di Eropa. Ia menulis, "Islam di kawasan Mediterranea adalah "citra-cermin" dari agama Kristen di Eropa". Kemiripan keduanya antara lain terletak pada perlawanannya terhadap kelompok mayoritas atau mainstream. Mereka kelompok minoritas yang ingin menarik dukungan masa dengan cara menawarkan diri sebagai pembawa berkah dan sebagai perantara antara manusia dengan Tuhan. ${ }^{46}$

Gagasan keduanya tentang masyarakat dan kepemimpinan juga memiliki kesamaan yang signifikan, menurut Gellner. Keduanya

\footnotetext{
${ }^{45}$ Gellner, Muslim Society, 104.

${ }^{46}$ Ibid., 132-3.
} 
menganut "sistem kasta" dan memiliki hierarki yang kaku. ${ }^{47}$ Dengan status sebagai wali (dalam tasawuf) dan wakil Tuhan (dalam gereja) murshid dan pastur memiliki otoritas absolut dan tak terbantahkan. Gellner merasa bahwa ungkapan "seorang murid di hadapan murshidnya sama dengan jenazah di hadapan orang yang memandikannya" sebagai bentuk pembodohan dan penyalahgunaan kekuasaan. Atas dasar ini, ia menyebut kepemimpinan para sufi otoritarian. ${ }^{48}$

Paparan Gellner ini layak digarisbawahi. Ada dua catatan yang harus ditegaskan dalam konteks ini. Pertama, pandangan Gellner tentang tasawuf dan masyarakat sufi memang kontradiktif. Dalam kesempatan yang berbeda ia tidak jarang mengungkapkan kekagumannya terhadap para sufi yang egaliter, modern, terbuka dan bahkan memiliki spirit kapitalisme yang tinggi. Namun dalam kesempatan yang lain ia mengatakan sebaliknya. Ia pernah menyebut masyarakat sufi sebagai "model" namun pernah pula menyebutnya "antitesis". Kontradiksi ini masih dapat ditengahi dengan mengatakan bahwa secara internal, masyarakat sufi adalah model. Ajarannya yang idealistik dan sejalan dengan nilai-nilai etis dan moral menjadikan tasawuf layak dilirik. Namun dalam konteks modernitas, tasawuf adalah antitesis karena menarik diri dari dunia dan megajarkan asketisme yang tidak sejalan dengan tujuan dan cita-cita modernitas.

Persoalannya adalah jika itu yang ia kehendaki, kontradiksi baru muncul. Gellner kadang memandang kaum sufi sebagai kelompok yang berada di luar ummah karena mereka sesat. Jika demikian, berarti tasawuf bukan Islam, dan secara logika tidak dapat dianggap sebagai model bagi umat Islam. Dan jika ia mengaggap tasawuf tetap bagian dari Islam, kenyataannya adalah ia menginginkan "Islam tanpa tasawuf'.

Inilah kerumitan yang terus lahir ketika pembacaan terhadap Gellner mengenai tasawuf dilakukan. Menata ulang pemikirannya agar tidak kontrandiktif terlalu sulit untuk dilakukan. Lagi pula itu adalah tugas yang bersangkutan. Tugas kita adalah membaca dan meneliti. Dan ketika penelitian dilakukan terlalu banyak kesalahan yang ditemukan. Kesalahan yang paling fatal adalah obsesinya yang terlalu

\footnotetext{
${ }^{47}$ Ernest Gellner, "Trust, Cohesion and the Social Order", dalam Trust: Making and Breaking Cooperative Relation, ed. Diego Gambetta (Oxford: University of Oxford, 2000), 153.

${ }^{48}$ Gellner, Muslim Society, 104-32.
} 
berlebihan untuk menjadikan modernitas sebagai standar kebenaran dan kebaikan. Tasawuf ia paksakan agar tunduk pada idealisme dan tujuan modernitas. Jika tidak, maka ia lantas menilainya salah. Ia lupa bahwa setiap masyarakat, budaya, atau agama memiliki konsepnya sendiri mengenai masyarakat, unsur-unsur kemasyarakatan, batasan masyarakat, dan sistem nilai. Modernitas sendiri yang ia perjuangkan adalah supermarket dengan banyak pilihah di dalamnya. Perbedaan menjadi keniscayaan dan heterogenitas (bukan homogenitas seperti yang ia kehendaki) adalah hukum.

Konsep masyarakat terlalu kompleks untuk diseragamkan menggunakan ukuran Gellner. Uniknya meski tidak ia lirik, tawaran "sufistik" mengenai model masyarakat menarik minat banyak orang sejak lama dan hingga kini. Plato, misalnya, menekankan konsep kesederhanaan sebagai mekanisme untuk menjaga ketahanan. Menurutnya, peradaban identik dengan kemewahan. Dalam peradaban yang mewah, kesederhanaan menjadi barang langka. Ia menulis: "Dalam kemajuan, sulit diwujudkan kesederhanaan". ${ }^{49}$ Maka ketika kesederhanaan punah, peradaban pun musnah.

Para sufi sangat fasih mengumandangkan visi kesederhanaan ini. Apa yang mereka ajarkan tidak bermaksud menjauhkan diri dari kemajuan. Kesederhanaan dalam bentuk zubd adalah mekanisme kontrol atas tindakan. Ibn Khaldūn sepakat dengan ini. Dalam konteks peradaban, zubd adalah jaminan solidaritas dan stabilitas. Awal dari kekacauan dan kehancuran adalah kemewahan dan kesenangan duniawi. Gairah dan syahwat keduniaan harus dikendalikan. Plato secara khusus mengingatkan kaum elit untuk tidak terlena. Ketersediaan fasilitas yang serba ada membuat mereka paling rentan untuk terjerumus ke dalam pola hidup yang berlebihan.

Seperti Plato dan para sufi, Ibn Khaldūn meyakini bahwa unsur paling penting dalam masyarakat bukan materi, melainkan tatanan nilai termasuk kesederhanaan dan kezuhudan. Sementara Gellner memandang kemajuan materi sebagai inti dari peradaban yang menjamin solidaritas, kohesi dan ikatan antarsesama, bagi Ibn Khaldūn inti dari itu semua itu adalah perilaku. Gellner menolak dasar-dasar pemikiran Ibn Khaldūn yang "sufistik" yang sejalan dengan Plato bahwa, a) kesederhanaan menjamin solidaritas dan kohesi sosial, b) ketika peradaban maju kohesi terancam, perpecahan terjadi dan kerusakan melanda. Dalam penilaian Gellner, ini

${ }^{49}$ Ibid., 17. 
menggiring manusia ke belakang ke "fase pedesaan" dan menghalangi mereka untuk memasuki "fase perkotaan".

Sinisa Malesevic yang merupakan "anak intelektual" Gellner justru tidak sepakat dengannya dan membela Ibn Khaldūn. Untuk konteks masyarakat tradisional, kezuhudan dan kemajuan adalah dua hal yang tidak dapat dipertemukan. Manusia harus memilih antara hidup asketis dan bisa kohesif walau tidak maju, atau hidup maju tapi bercerai-berai..$^{50}$

\section{Tasawuf tanpa Tarekat}

Masyarakat modern bukanlah masyarakat tradisional. Pemahaman Ibn Khaldūn tentang 'asabiyah yang ia rangkai dalam situasi "pedesaan" harus diperluas agar mencakup konteks "perkotaan". Ibn Khaldūn pernah memilih "kezuhudan demi keutuhan" daripada "kemajuan lantas kehancuran". Kini pandangannya perlu ditafsirkan ulang.

Konsep asabiyah bersifat fleksibel dan dapat diartikan sesuai dengan konteks yang mengitarinya. Arnason dan Stauth memahaminya bukan saja sebagai mekanisme solidaritas antarmanusia yang terjalin karena "hubungan kesamaan" dalam hal keturunan, kesukuan, kebangsaan atau keagamaan, melainkan juga sebagai "kapasitas dan kemauan untuk membentuk kehendak bersama dan komitmen untuk melakukan tindakan tertentu". ${ }^{51}$ Dengan pengertian ini, asabiyah tidak saja tentang "hubungan kesamaan" melainkan juga tentang "hubungan kebersamaan".

Dalam banyak hal, teori asabiyah gubahan Arnason dan Stauth ini menyerupai konsep social contract yang digagas oleh Jean-Jacques Rousseau dan dilanjutkan antara lain oleh Robinson Crusoe. Kontrak sosial meniscayakan adanya kesepakatan yang terjalin antarindividu dalam sebuah kelompok sebagai syarat paling dasar tidak saja bagi terbentuknya masyarakat namun juga bagi kelanjutannya. Kesepakatan adalah jaminan masyarakat dapat bertahan sebagaimana ketiadaannya adalah penyebab bagi kehancurannya. Semakin solid, jelas dan kuat kesepakatan ini, semakin kuat pula jalinan dalam masyarakat.

\footnotetext{
${ }^{50}$ Sinisa Malesevic, "Where does Group Solidarity Come From? Gellner and Ibn Khaldūn Revisited”, Thesis Eleven (Juni, 2015), 1-15.

51 Arnason J.P. dan Stauth G., "Civilisation and State Formation in the Islamic Context: Re-reading ibn Khaldūn”, Thesis Eleven, 76 (Februari, 2004), 29-47.
} 
Dalam teori ini kesepakatan melahirkan komitmen dan kehendak. Sekumpulan manusia, berapapun jumlahnya, dapat disebut masyarakat selama ada kontrak di dalamnya. Atas dasar ini, Gellner keliru ketika tidak menganggap tarekat sebagai masyarakat. Padahal dalam tarekat tidak saja ada kelompok, namun juga ada kehendak, komitmen, kebersamaan, bahkan nilai. Sebagaimana masyarakat tarekat juga memenuhi syarat paling berat yang diajukan oleh Ibn Khaldūn, yaitu keterpanggilan anggotanya untuk saling menjaga, melindungi, menyayangi dan mencitakan kebersamaan..$^{2}$

Gellner pernah berkilah bahwa melihat masyarakat dari sudut pandang keyakinan agamanya adalah langkah yang salah. ${ }^{53}$ Agama ia coret sebagai motif mengapa manusia mau bermasyarakat. Ini aneh padahal agama, menurut Engels seorang Marxist dan materialis, adalah motif paling kuat bagi manusia untuk berkelompok. Motif lain seperti harta, jabatan dan kesenangan berada di bawahnya. Memang kadang Gellner bersedia mengakui peran agama, namun hanya dalam batas masyarakat pedesaan dan tradisional saja. Hal ini tidak berlaku untuk masyarakat modern. ${ }^{54}$

Argumentasi Gellner ini melupakan fakta yang paling nyata tentang eksodus manusia dalam jumlah besar dari kegersangan duniawi menuju agama. Fenomena maraknya orang yang bergabung dengan gerakan New Age Cult (Gemeinschaft) di Eropa, atau aliran Pantekosta di Amerika Latin, atau bahkan dengan tasawuf tidak saja di dunia Islam namun juga di belahan dunia lainnya adalah bukti agama tetap bertenaga. Untuk Indonesia, kegiatan keagamaan seperti pengajian dan majelis taklim justru semakin hari semakin ramai baik di pedesaan maupun perkotaan. Teori Gellner benar hanya untuk situasi awal abad lalu hingga awal abad ini ketika agama tertekan oleh modernitas.

Yang terjadi sekarang adalah sebaliknya atau setidaknya agama sudah mampu memberikan perlawanan terhadap modernitas. Salah satu aliran pemikiran yang merupakan pilar modernitas, yaitu individualisme, mulai dipertanyakan. Aliran ini adalah kebanggaan Gellner. Sudah banyak yang meragukan keabsahan premis kesenangan dan kepuasan individu sebagai standar keutuhan masyarakat. Individualisme ala Robinson Crusoe, Descartes, Hume hingga Kant

\footnotetext{
${ }^{52}$ Ibn Khaldūn, Muqaddimah (Beirut: Dār al-Fikr, 1998), 98.

${ }^{53}$ Gellner, Muslim Society, 114.

${ }^{54}$ Ibid., 115.
} 
yang dikemas dalam neo-liberalisme juga tidak lagi laku. Aliran ini mempersembahkan gagasan bahwa individu mampu membuat dunianya sendiri tanpa bantuan dari kekuatan lain di luar dirinya. Sama dengan materialisme, asumsi dasarnya adalah bahwa kebahagiaan individu terletak pada ketercukupan materinya, bukan pada keagamaannya atau kepatuhannya pada norma. ${ }^{55}$

Gellner sendiri ketika sadar akan kerapuhan individualisme menganggapnya tidak ideal karena tidak memperhatikan aspek etika. Budaya individualis tidak mampu menciptakan dimensi tertentu dalam budaya manusia, seperti rasa memiliki terhadap kelompok, kerjasama dengan orang lain, dan rasa hormat terhadap lingkungan dan sesama manusia. Ia menyadari bahwa individualisme adalah tatanan tanpa nilai. ${ }^{56}$ Ekstremnya, individualisme adalah ancaman tidak saja bagi agama dan masyarakat tradisional melainkan juga bagi peradaban dan masyarakat modern itu sendiri. Individu yang terlalu bebas dan cenderung tanpa batas akan menciptakan egoisme pada tataran pribadi maupun kolektif. Segalanya akan kembali kepada "aku". Norma, hukum bahkan agama akan kehilangan tempatnya. Gellner bahkan menyebut, dalam masyarakat individualis hanya ada satu "nilai" yang tersisa, yaitu kesetiaan terhadap kelompok dan idealisme. ${ }^{57}$ Itupun tidak ada jaminan nilai ini akan dapat bekerja karena masih tergantung pada kehendak dan kemauan sang "aku".

Ini artinya, Gellner secara sadar menolak pandangannya sendiri dan mendukung tesis bahwa era modern ini berada di tangan agama, bukan modernitas. Dalam situasi apapun, agama terbukti tetap memiliki daya untuk melahirkan kehendak, komitmen, tindakan dan pada akhirnya peradaban. Dalam kerangka teori asabiyah, agama adalah mekanisme menciptakan kontrak sosial.

Tasawuf berada dalam naungan agama. Sebagai kekuatan besar, ia memiliki peran penting dalam menentukan masa depan peradaban manusia. Bagaimana tasawuf bekerja, secara garis besar, tergantung pada mekanisme agama. Moralitas yang merupakan pondasinya berasal dari agama. Demikian pula dengan landasan teologis dan metafisisnya. Namun untuk urusan teknis-sosiologis, tasawuf, atau persisnya tarekat, seringkali menciptakan kerangkanya sendiri, atau

55 Ernest Gellner, Language and Solitude: Wittgenstein, Malinowski and the Hobsburg Dilemma (Cambridge: Cambridge University Press, 1998), 7-13.

${ }^{56}$ Musil, “Gellner's Philosophy of History, 167.

${ }^{57}$ Gellner, Muslim Society, 92. 
memiliki apa yang oleh para pakar sosiologi disebut centripetal forces. Dua pertanyaan yang patut diajukan kemudian adalah, jenis ikatan seperti apa yang terbangun dalam tarekat? Dan, bagaimana ikatan itu terjalin? Atau, masyarakat seperti apa yang dapat kita bayangkan dalam tarekat, dan batasan apa yang dapat kita gunakan untuk menilai masyarakat ini?

Pilihan yang dapat dijadikan kriteria bagi masyarakat sangatlah banyak sebanyak jumlah aliran pemikiran filosofis, sosiologis bahkan keagamaan yang pernah ada. Di tengah banyaknya pilihan itu, tawaran spiritual sayangnya masih minim, dan cenderung dilupakan. Sejumlah orang tidak melirik potensi tarekat sebagai masyarakat mungkin karena masih menyangka bahwa tasawuf adalah sistem pemikiran yang tidak memiliki dimensi sosial-praktis. Padahal sebagai sistem pemikiran, tasawuf, tidak seperti filsafat, mencoba menjawab pertanyaan "apa yang kita lakukan di dunia ini" dan "bagaimana kita melakukannya". Pertanyaan mendasar ini seharusnya sudah cukup sebagai kriteria bahwa tasawuf mengandung unsur sosial. ${ }^{58}$

Gagasan asabiyah ala Arnason dan Stauth, dan teori kontrak sosial yang sudah disebut di atas meniscayakan bahwa sekelompok orang sudah dapat disebut masyarakat karena kriteria tertentu. Para penjelajah adalah masyarakat karena untuk bertahan hidup mereka membangun hubungan, ikatan dan kerjasama. Kaum petani adalah masyarakat karena memiliki ikatan budaya yang membedakan mereka dengan kaum aristokrat dan yang lain. Masyarakat industrial juga masyarakat karena mewujudkan pertumbuhan ekonomi, melakukan identifikasi nasional dan menciptakan nasionalisme. ${ }^{59}$ dengan demikian, jika hobi, pekerjaan, ilmu pengetahuan, ditambah dengan etnis, kebangsaan, bahasa, dan budaya dapat dijadikan sebagai kriteria masyarakat, seharusnya agama yang di dalamnya terdapat spiritualitas, etika, moralitas, nilai kebaikan dan kebajikan juga demikian.

Kajian sosiologis yang dilakukan oleh Durkheim menemukan dua jenis masyarakat, yaitu mekanik dan organik. Yang pertama terbentuk karena adanya kesamaan dalam hal keturunan, kesukuan atau nasionalisme, sedangkan yang kedua terbentuk karena adanya sikap saling ketergantungan dan saling membutuhkan. Yang pertama dapat disebut "masyarakat kesamaan" dan yang kedua "masyarakat kebersamaan". Dalam wacana Ibn Khaldūn hanya dikenal jenis

\footnotetext{
${ }^{58}$ Musil, “Gellner's Philosophy of History, 167.

${ }^{59}$ Lihat Malesevic, "Where does Group Solidarity Come From?"
} 
pertama saja, namun beberapa orang telah menafsirkan ulang teorinya mengenai asabiyah sehingga mencakup jenis yang kedua.

Jenis yang pertama tumbuh subur dalam masyarakat tradisional, sedangkan yang kedua dalam masyarakat modern. Gellner memandang bahwa masyarakat industrial adalah model par excellence untuk jenis kedua. Dalam masyarakat ini, profesionalitas dan pembagian kerja tingkat tinggi telah menjelma menjadi semacam perekat. Pergerakan warganya yang cepat menuntut adanya pengikat agar disintegrasi tidak terjadi. Tingkat pendidikan yang tinggi disertai dengan wawasan, kesadaran dan kesetian terhadap nilai-nilai nasionalisme ditengarai menjadi jaminan bahwa "masyarakat kebersamaan" dapat menjaga solidaritas dan kohesinya. Bahkan perbedaan sekalipun, seperti yang terjadi di Swiss dengan perbedaan bahasanya, dapat dimanfaatkan sebagai perekat antarwarga. ${ }^{60}$

Sisi lain harapan untuk hidup lebih sejahtera dan bebas adalah faktor yang membuat roda masyarakat industrial tetap berputar. Mentalitas materialistik menjadi pendorong manusia industrial untuk mengejar keuntungan material. Tidak ada monopoli dalam masyarakat ini. Semua orang memiliki kesempatan yang sama untuk maju dan berkembang. Keahlian dan penguasaan terhadap pengetahuan tertentu, bukan budaya atau agama, adalah apa yang membuat seseorang dianggap sebagai bagian dari warga masyarakat ini.

Persamaan hak adalah slogan yang paling menonjol. Namun karena para ahli dan cerdik cendekia mendapat tempat istimewa, kaum papa dengan mudah akan terpinggirkan. Kesejahteraan tersentral pada kaum profesional. Yang ada di pinggiran akan tetap terpinggirkan. Empati dan simpati kepada kaum lemah tipis. Semua orang ingin dihargai sesuai dengan keahliannya. Keinginan mendapat penghargaan lebih kuat. Perlombaan dan persaingan sangat ketat. Yang kalah akan terlempar dan yang menang akan sesumbar.

Bahaya disintegrasi selalu mengancam dalam masyarakat ini. Sebagai antisipasinya, menurut Gellner, di samping melakukan apa yang ia sebut sebagai "internalisasi kesetiaan terhadap nilai-nilai nasionalisme", juga harus ada upaya penyeragaman budaya. Manusia dengan latar belakang budaya yang berbeda harus digiring agar mengadopsi satu budaya, yaitu modernitas dengan tiga pilarnya. ${ }^{61}$

${ }^{60}$ Gellner, Muslim Society, 95.

61 Ibid., 94. 
Ini semua sekali lagi mengingatkan kita kepada Ibn Khaldūn dengan teorinya "kemajuan lantas kehancuran". Kebersamaan dan keutuhan yang terbangun dalam masyarakat modern lebih bersifat semu dan sesaat. Ancaman disintegrasi selalu menghantui. Asketisme menjadi barang mewah yang diidam-idamkan.

Sementara itu masyarakat Muslim yang Gellner sebut "segmentary" digolongkan ke dalam jenis masyarakat pertama namun dengan potensi menjadi masyarakat jenis kedua. Pandangan Gellner yang membingungkan tentang masyarakat Muslim dapat dimediasi dengan mengatakan: pertama, masyarakat Muslim termasuk tradisional; kedua, kelompok reformis dalam masyarakat ini dapat digolongkan ke dalam jenis kedua yang modern, dan; ketiga, masyarakat Muslim yang tradisional memiliki potensi untuk bertransformasi menjadi modern tanpa harus kehilangan identitas tradisionalnya.

Dalam sebuah kesempatan Gellner pernah menaruh kekagumannya pada tarekat yang ia sebut "contoh dari organisasi tradisional dalam Islam yang mampu beradaptasi dengan kondisi modern". ${ }^{2}$ Tingkat fleksibilitasnya tinggi sehingga "mampu melakukan penyesuaian dengan kemodernan tanpa harus keluar dari orbtodoxy". ${ }^{63}$ Merujuk kepada hasil penelitian Donal Brian Cruise O’Brien terhadap Tarekat Qādirīyah pimpinan Amadu Bamba di Senegal, Gellner mengakui beberapa tarekat cukup maju secara ekonomi dan memiliki "spirit of capitalism" yang kuat. ${ }^{64}$

Ia mengajarkan bahwa masyarakat tradisional tidak punya kesempatan untuk bertahan hidup di era modern. Semakin tradisional sebuah masyarakat semakin besar pula peluangnya untuk punah dihantam gelombang modernitas. Namun ia terkejut ketika menemukan tarekat yang ultra-tradisional, ultra-konservatif, irrasional, otoriter, kolot, jumud dan ketinggalan zaman justru dapat bertahan dan bahkan memberi perlawanan terhadap modernitas. ${ }^{65}$ Modernitas menyuarakan kebebasan, keterbukaan, rasionalitas, dan persamaan. Modernitas yang mengkultuskan kemajuan ekonomi akan membekuk tarekat yang memuja kuburan para wali. ${ }^{66}$ Namun, kenyataannya tidak demikian.

\footnotetext{
62 Ibid., 104.

${ }^{63}$ Ibid.

${ }^{64}$ Lihat Donal Brian Cruise O’Brien, The Mourides of Senegal: The Political and Economic

Organisation of an Islamic Brotherhood (Oxford: Clarendon, 1971).

${ }^{65}$ Gellner, Muslim Society, 104.

${ }^{66}$ Ibid.
} 
Kebingungan Gellner terjadi karena pemahamannya yang keliru tentang modernitas dan tasawuf-tarekat. Asumsinya salah sejak awal. Ia mengira bahwa seolah seisi dunia sudah modern, padahal lebih dari setengah penduduk bumi masih hidup dalam suasana tradisional dan berpedoman pada nilai-nilai tradisional. Ia juga keliru ketika menganggap tarekat identik dengan keterbelakangan, padahal di samping aspek ekonomi yang menjadi kekuatannya, tarekat juga memiliki keunikan lain setidaknya pada tiga aspek.

Pertama, aspek kepemimpinan. Konsep masyarakat yang dibangun oleh para sufi bertumpu pada sosok murshid yang karismatik. Kepatuhan dan ketundukan para murid menjamin keberlangsungan organisasi. Kesetian adalah salah satu ciri tarekat sekaligus menjadi sumber kekuatannya. Seorang murid biasanya akan dibaiat oleh murshid demi menanamkan kesetiaan ini. Karena alasan inilah, keanggotan tarekat cenderung konstan, stabil dan tidak banyak mengalami perubahan. Ini tidak banyak ditemukan dalam organisasi sosial lain. Dalam tarekat tidak sulit memahami mengapa organisasi ini solid dan memiliki solidaritas tinggi. Kepada siapa para murid harus percaya dan menyandarkan diri, sudah jelas. Ini berbeda dari masyarakat modern yang tidak mengetahui kepada siapa mereka menaruh kepercayaan. Dalam tarekat, jaringan individu sudah terbangun karena adanya keanggotaan yang konstan dan pemimpin yang dianut. Murshid menciptakan ikatan yang kuat antara pemimpin dan anggota pada satu sisi, dan antara sesama anggota pada sisi lain.

Dalam kajian sosiologi agama, ikatan emosional dalam sebuah organisasi serta kepatuhan dan ketundukan kepada pemimpinnya merupakan faktor penting yang menjaga kesatuan dan kebersatuan organisasi. Pendapat ini antara lain disampaikan oleh Randall Collins ${ }^{67}$ dan Jonathan Turner, ${ }^{68}$ dan dituangkan antara lain dalam teori romantic organisism.

Kedua, aspek visi. Pada aspek ini tarekat unik dan berbeda dari umumnya organisasi. Motif tarekat biasanya tidak bersifat duniawi atau materi, melainkan demi tercapainya "social welfare". Meminjam istilah ekonomi, tarekat adalah "capitalism without capital" di mana yang dicari adalah kebahagiaan bukan keuntungan, ketenangan bukan

${ }^{67}$ Lihat Randall Collins, Interaction Ritual Chains (Princeton: Princeton University Press, 2004).

${ }^{68}$ Lihat Jonathan Turner, Human Emotions: A Sociologial Theory (London: Routledge, 2007). 
kepuasan, pencerahan bukan kesenangan. Kebaikan adalah nilai yang ingin diwujudkan bersama. Masyarakat ini bersifat organik, meminjam Durkheim. Sistem yang menciptakan solidaritas dan kohesi bekerja tidak semata karena adanya persamaan suku, bahasa, atau yang lain, juga bukan karena dorongan profesional atau material, melainkan karena motif spiritual dan kebaikan. Para pakar sosiologi kira-kira akan menyangsikan kemungkinan kebaikan menjadi landasan masyarakat. Namun ahli sejarah akan menerima, karena fakta-fakta sejarah menunjukkan demikian. Penganut teori ekonomi kesejahteraan juga akan sepakat karena mengerti kesejahteraan tidak melulu tentang distribusi kekayaan tapi juga tentang keadilan dan keseimbangan antara dimensi material dan moral-spiritual.

Ketiga, aspek kohesi sosial. Sejak kelahirannya, tarekat adalah jawaban atas fenomena degradasi moral dan alternatif bagi persoalan disintegrasi sosial. Mengacu kepada pemikiran Ibn Khaldūn, kesederhanaan lebih menjamin terciptanya kohesi sosial karena mengurangi peluang terjadinya perselisihan akibat persaingan yang tidak sehat. Kemajuan yang didukung oleh sistem nilai yang lemah dan pemerintah yang korup, masih menurutnya, adalah sumber utama terjadinya keretakan sosial. ${ }^{69}$ Untuk konteks sekarang, modernitas dengan pemikirannya yang liberal dan pola hidup masyarakatnya yang bebas jelas merupakan tantangan bagi tasawuf dan tarekat.

Uniknya, secara historis tarekat justru akan bertumbuh semakin kuat ketika tantangan yang ia hadapi semakin besar. Asumsi Gellner bahwa modernitas akan menggilas tarekat adalah salah. Yang terjadi adalah sebaliknya di mana dengan tarekat, modernitas justru akan menemukan kelemahannya sendiri. Temuan Ibn Khaldūn dan Durkheim tentang mekanisme pertahanan masyarakat tradisional mendukung tesis ini. Menurut mereka, masyarakat yang hidup dalam kondisi alam yang keras, dengan ancaman dari lingkungan dan sekelilingnya, akan melakukan apa saja untuk bertahan. Bahwa tarekat masih bertahan dan bahkan terus berkembang menunjukkan ancaman modernitas adalah berkah. Gellner juga keliru ketika mengatakan tarekat tidak dapat berkembang di perkotaan. Justru di tempat seperti inilah, ikatan antar-pengikut semakin kuat. Di Tanah Air, beberapa tarekat seperti Tarekat Qādirīyah wa Naqshabandìyah (TQN) tumbuh besar di perkotaan dan mampu menarik minat dan perhatian kalangan terdidik dan profesional.

${ }^{69}$ Gellner, "Trust, Cohesion and the Social Order", 144. 
Hanya saja, yang patut dicatat adalah sifat solidaritas dalam setiap masyarakat dan organisasi akan terus berubah seiring dengan perubahan sosial di sekitarnya. Tarekat tidak boleh hanya mengurusi ritual dan pengajian jika mau berkembang. Mereka harus memperkuat aspek lain seperti pendidikan, sosial dan ekonomi. Beberapa tarekat sudah melakukan ini dengan keberhasilan yang beragam. Karena pembaharuannya, sebagian tarekat layak menjadi "masyarakat kebersamaan" yang modern. Namun sebagian yang lain masih mempertahankan karakternya sebagai "masyarakat kesamaan" yang fokus pada aspek kesamaan niat untuk meraih pencerahan batin. Sebagai "masyarakat kesamaan" keberhasilan tarekat menjaga solidaritas dan kohesinya sangat tergantung pada norma dan kebaikan hati individu yang ada di dalamnya. Namun sebagai "masyarakat kebersamaan" keberhasilan itu tergantung tidak saja pada norma, namun juga pada sistem dan tata kelola organisasi.

\section{Catatan Akhir}

Pemaknaan yang sedikit berbeda tentang tasawuf dan tarekat sebagai "masyarakat kebersamaan" pernah coba dilakukan oleh Maruyama Daisuke. Pendapatnya layak dikutip sebagai penutup pembahasan ini. Gagasan utamanya adalah bahwa tasawuf dan tarekat terus mengalami perubahan salah satunya adalah perubahan dari sistem pengetahuan (tasawuf) dan sistem perilaku (tarekat) menjadi apa yang ia sebut popular practice, semacam perayaan keagamaan. ${ }^{70}$ Mengutip Yasushi Tonaga, ia menjelaskan bahwa tasawuf memiliki tiga dimensi, yaitu mistis, etis, dan populer atau perayaan rakyat. Dasuke lalu menambahkan satu lagi yaitu dimensi komunal. ${ }^{71}$

Dimensi mistis adalah aspek ajaran dan gagasan yang bermaksud mengantarkan seorang sufi agar dapat "bersama dengan Allah". Dimensi etis mengajarkan bagaimana seorang sufi berperilaku baik terhadap "sesama manusia". Dimensi populer membimbing sufi untuk "bersama berada di jalan Allah", sedang dimensi komunal menuntun sufi agar dapat "bersama dengan sesama sufi". ${ }^{72}$ Jadi, ada empat tingkat kebersamaan, yaitu bersama Allah, bersama sesama manusia, bersama berada di jalan Allah, dan bersama sesama sufi.

70 Maruyama Daisuke, "Redefining Sufism in Its Social and Political Contexts: The Relationship between Sufis and Salafis in Contemporary Sudan", Kyoto Bulletin of Islamic Area Studies, 8 (Maret, 2015), 40-56.

${ }^{71}$ Ibid.

72 Ibid. 
Dimensi populer dan komunal memiliki kesamaan dan perbedaan. Perbedaannya adalah bahwa yang populer bersifat inklusif karena setiap orang, tidak harus sufi, dapat bergabung di dalamnya, sedangkan yang komunal bersifat eksklusif karena diperuntukkan hanya untuk kaum sufi. Persamaannya adalah, baik pada tataran inklusif maupun eksklusif, tasawuf dan tarekat memiliki kapasitas untuk menciptakan solidaritas dan kohesi sosial karena individu-sufi terdorong untuk mengidentifikasi dirinya dengan kelompok ini. Pada dimensi populer, identifikasi yang dilakukan bisa saja bersifat dangkal, tapi tidak demikian dengan dimensi komunal. Dalam dimensi ini individu menunjukkan keterikatan yang kuat terhadap kelompoknya. Mereka memiliki komitmen yang mendalam terhadap komunitas sufi yang berakar pada tasawuf dan tarekat. ${ }^{73}$ Dari sinilah, solidaritas yang melahirkan kohesi dan keutuhan organisasi tercipta.

\section{Daftar Rujukan}

Arnason J.P. dan Stauth G., "Civilisation and State Formation in the Islamic Context: Re-reading ibn Khaldūn", Thesis Eleven, 76, Februari, 2004.

Asad, Talal. "The Concept of Cultural Translation in British Social Anthropology", dalam James Clifford dan George Marcus (eds.), Writing Culture: The Poetics and Politics of Ethnography. Berkeley: University of California Press, 1986.

----. "The Idea of an Anthropology of Islam", dalam John A. Hall dan Ian Charles Jarve (eds.), The Social Philosophy of Ernest Gellner. Amsterdam dan Atlanta: Rodopi, 1996.

. The Idea of an Anthropology of Islam. Washington DC: Georgetown University Centre of Contemporary Arab Studies, 1986.

Collins, Randall. Interaction Ritual Chains. Princeton: Princeton University Press, 2004.

Daisuke, Maruyama. "Redefining Sufism in Its Social and Political Contexts: The Relationship between Sufis and Salafis in Contemporary Sudan", Kyoto Bulletin of Islamic Area Studies, 8, Maret, 2015.

Dannreuther, Roland dan Kennedy, James. "The International Relations of the "Transition": Ernest Gellner's Social Philosophy and Political Sociology", Makalah--SGIR Par European Conference, Torino, 12-15 September, 1999.

${ }^{73}$ Ibid. 
Gellner, Ernest. "The Civil and the Sacred" Makalah--Harvard University, 20-21 Maret 1990.

----. "Trust, Cohesion and the Social Order", dalam Trust: Making and Breaking Cooperative Relation, ed. Diego Gambetta. Oxford: University of Oxford, 2000.

----. Language and Solitude: Wittgenstein, Malinowski and the Hobsburg Dilemma. Cambridge: Cambridge University Press, 1998.

----. Muslim Society. Cambridge: Cambridge University Press, 1995.

----. Nations and Nationalism. Ithaca: Cornell University Press, 1983.

----. Plough, Sword and Book: The Structure of Human History. Harville: Collins, 1988.

----. Postmodernism, Reason, and Religion. London dan New York: Routledge, 1992.

Hall, John A. dan Jarve, Ian Charles (eds.). The Social Philosophy of Ernest Gellner. Amsterdam and Atlanta: Rodopi, 1996.

Hall, John A. Emest Gellner: An Intellectual Biography. London, New York: Verso, 2011.

Hume, David. Natural History of Religion. Stanford: Stanford University Press, 1957.

Khaldūn, Ibn. Muqaddimah. Beirut: Dār al-Fikr, 1998.

Lessnoff, Michael. Ernest Gellner and Modernity. Wales: University of Wales Press, 2002.

Lewis, Bernard. The Political Languange of Islam. Chicago: Chicago University Press, 1988.

Maleseciv, Sinisa dan Haugaard, Mark (eds.). Ernest Gellner and Contemporary Social Thought. New York: Cambridge University Press, 2007.

Malesevic, Sinisa. "Where does Group Solidarity Come From? Gellner and Ibn Khaldūn Revisited", Thesis Eleven, Juni, 2015.

McLoughlin, Sean. "Islam (s) in Context: Orientalism and the Anthropology of Muslim Societies and Cultures", Journal of Beliefs and Values, Vol. 28, No. 3, 2007.

Mohanty, Satya P. Literary Theory and the Claims of History. Ithaca dan London: Cornell University Press, 1997.

Musil, Jiri. "Gellner's Philosophy of History: Interpretations and Problems", dalam John A Hall (ed.), The Social Philosophy of Emest Gellner. Netherlans: Brill Rodopi, 1996. 
O'Brien, Donal Brian Cruise. The Mourides of Senegal: The Political and Economic Organisation of an Islamic Brotherhood. Oxford: Clarendon, 1971.

Rendu, Comptes. "Book Reviews: Ernest Gellner and Contemporary Social Thought", Canadian Journal of Sociology, Vol. 34, No. 1, 2009. Riyadi, Abdul Kadir. Antropologi Tasawnf. Jakarta: LP3ES, 2014.

Turner, Jonathan. Human Emotions: A Sociologial Theory. London: Routledge, 2007.

Tylor, Charles. A Secular Age. Cambridge: Belknap Press, 2007.

Varisco, Daniel Martin. Islam Obscured: The Rhetoric of Anthropological Representation. New York: Palgrave McMillan, 2005.

Zubaidah, Sami. "Is There a Muslim Society? Ernest Gellner's Sociology of Islam", Journal of Economy and Society, Vol. 24, No. 2, 1995. 